\title{
PERBANDINGAN MODEL PEMBELAJARAN KOOPERATIF TIPE NHT DAN TAI TERHADAP KEMAMPUAN PEMAHAMAN KONSEP MATEMATIS SISWA
}

\author{
${ }^{1}$ Maya Lestari \\ ${ }^{1}$ Pendidikan Matematika, Fakultas Keguruan dan Ilmu Pendidikan, Universitas Muhammadiyah Sukabumi \\ 1mayalestari209@gmail.com
}

\begin{abstract}
Abstrak
Penelitian ini bertujuan untuk mengetahui perbandingan kemampuan pemahaman konsep matematis antara siswa yang memperoleh model pembelajaran NHT dengan siswa yang memperoleh model pembelajaran TAI dan siswa yang memperoleh model pembelajaran langsung. Metode penelitian yang digunakan adalah metode kuasi-eskperimental dengan desain posttest control group design. Populasi pada penelitian ini adalah seluruh siswa kelas VIII SMPN 16 Kota Sukabumi. Sampel penelitian ini ada 3 kelas. Instrumen yang digunakan yaitu soal pemahaman konsep dan lembar observasi. Hasil penelitian ini yaitu (1) Terdapat perbedaan kemampuan pemahaman konsep matematis siswa yang belajar menggunakan model pembelajaran NHT, model pembelajaran TAI, serta model pembelajaran langsung, (2) Kemampuan pemahaman konsep matematis siswa yang belajar menggunakan model pembelajaran NHT lebih baik daripada siswa yang belajar dengan model pembelajaran TAI, (3) Kemampuan pemahaman konsep matematis siswa yang menggunakan model pembelajaran NHT lebih baik daripada siswa yang belajar dengan model pembelajaran langsung, (4) Kemampuan pemahaman konsep matematis siswa yang menggunakan modep pembelajaran TAI tidak lebih baik dengan siswa yang belajar dengan model pembelajaran langsung.
\end{abstract}

Kata Kunci : Model pembelajaran NHT, Model pembelajaran TAI, pemahaman konsep matematis.

\section{PENDAHULUAN}

Berdasarkan Undang-Undang No. 20 Tahun 2003 tentang Sistem Pendidikan Nasional menyatakan bahwa "Pendidikan adalah usaha sadar dan terencana untuk mewujudkan suasana belajar dan proses pembelajaran agar peserta didik secara aktif mengembangkan potensi dirinya untuk memiliki kekuatan spiritual keagamaan, pengendalian diri, kepribadian, kecerdasan, akhlak mulia, serta keterampilan yang diperlukan bagi dirinya, masyarakat, bangsa dan Negara". Menurut Monica (2015: 2) Pendidikan adalah usaha sadar dan terencana untuk mewujudkan suasana belajar dan proses pembelajaran agar siswa secara aktif mengembangkan potensi dirinya untuk memiliki keinginan yang kuat dalam belajar. Berdasarkan pemaparan tersebut dapat diartikan bahwa pendidikan merupakan salah satu sarana yang sangat penting bagi kelangsungan hidup manusia.

Matematika merupakan salah satu mata pelajaran yang diajarkan di setiap jenjang pendidikan. Menurut Sulaeman (2013: 2) menyatakan bahwa Matematika adalah mata pelajaran yang dikenal sulit oleh banyak orang. Ini sejalan dengan pendapat Ramlan (2013: 111) bahwa mendengarkan kata "matematika" saja, kebanyakan siswa akan merasakan kesan yang tidak menyenangkan. Mereka membayangkan angka-angka yang rumit, rumus-rumus yang sulit dimengerti, akibatnya pada hasil akhirnya, prestasi belajar matematika siswa masih dianggap rendah, sehingga kualitas pembelajaran matematika juga masih dianggap rendah.

Salah satu tujuan matematika pada pendidikan adalah agar siswa memiliki kemampuan memahami konsep matematika, menjelaskan keterkaitan antar konsep dan mengaplikasikan konsep, secara luwes, akurat, efisien, dan tepat dalam pemecahan masalah dimana kita ketahui bersama peranan penting matematika dalam mendukung proses manusia menjalani kehidupan (Suleman, 2013: 2). Kemampuan siswa yang rendah dalam menyelesaikan soal matematika yang berkaitan dengan pemahaman konsep tentunya menjadi masalah dalam pembelajaran matematika (Suleman, 2013: 2). Ini sejalan dengan Syaifudin (2013: 12) yang menyatakan bahwa pembelajaran matematika cenderung pada pencapaian target kurikulum dan buku pegangan, bukan pada pemahaman bahan yang dipelajari. Siswa cenderung menghafalkan konsep-konsep matematika yang diberikan guru yang sesuai dalam buku, tanpa memahami maksud dan isinya.

Permasalahan yang saat ini dihadapi oleh guru mata pelajaran matematika di sekolah adalah penguasaan siswa terhadap beberapa materi pokok bahasan matematika, terutama untuk mengingat konsep dalam waktu terbatas yang telah diajarkan (Anggoro, 2015: 72). Berdasarkan pendapat tersebut dapat ditarik kesimpulan bahwa permasalahan yang saat ini terjadi di sekolah adalah 
penguasaan siswa terhadap beberapa materi pokok bahasan matematika, terutama untuk mengingat konsep dalam waktu terbatas matematika pembelajaran cenderung pada pencapaian target kurikulum dan buku pegangan, bukan pada pemahaman bahan yang dipelajari. Sejalan dengan pendapat di atas maka dapat disimpulkan bahwa permasalahan yang terjadi dalam pembelajaran matematika disekolah adalah kurangnya pemahaman konsep matematis siswa.

Berdasarkan hasil wawancara kepada guru matematika kelas VIII di SMPN 16 Kota Sukabumi nilai UTS semester genap tahun ajaran 2016/2017 yang mencapai nilai lebih dari 70 hanya 10,11\%. Banyak faktor yang menyebabkan permasalahan tersebut. Menurut Syaifuddin (2013: 12) dalam pembelajaran matematika dengan cara langsung kegiatan belajar mengajar banyak didominasi oleh guru, sehingga yang aktif adalah guru. Dengan demikian peserta didik cenderung pasif, hanya mendengarkan, memperhatikan, dan mencatat apa yang telah diterangkan oleh guru. Hal ini menyebabkan peserta didik cenderung malas berfikir untuk mengerjakan tugas yang diberikan oleh guru dan tidak sedikit peserta didik yang merasa jenuh dalam mengikuti pelajaran matematika. Dapat disimpulkan bahwa salah satunya penyebab permasalahan di sekolah adalah guru masih menggunakan model pembelajaran langsung sehingga berdampak pada proses pembelajaran yang membosankan karena hanya mendengarkan dan mengerjakan soal saja.

Oleh karena itu dibutuhkan suatu model pembelajaran yang bervariasi. Pemilihan model pembelajaran yang tepat sangat dibutuhkan di sekolah tersebut. Model pembelajaran yang mampu membuat siswa ikut aktif dalam pembelajaran serta model yang mampu meningkatkan pemahaman konsep siswa. Ini sejalan dengan pendapat Suprijono (dalam Rosyad,2014: 64) melalui model pembelajaran, guru dapat membantu peserta didik mendapatkan informasi, ide, keterampilan, cara berfikir dan mengekspresikan ide. Model pembelajaran berfungsi pula sebagai pedoman bagi para perancang pembelajaran dan para guru dalam merencanakan aktivitas belajar mengajar. Apabila situasi tersebut tidak diperbaiki maka dari segi aspek kognitifnya berdampak tidak berkembangnya pemahaman siswa ke taraf yang lebih tinggi, dan dari segi afektinya yaitu kurangnya minat belajar siswa dalam mata pelajaran matematika serta rendahnya motivasi siswa dalam mata pelajaran matematika. Untuk kualitas proses pembelajarannya pun akan rendah.

Penerapan model pembelajaran kooperatif bisa menjadi salah satu solusi untuk permasalahan tersebut. Menurut Ramlan (2013: 111) Model pembelajaran kooperatif dianggap efektif dalam belajar matematika.
Menurut Alie (2013: 584) Pembelajaran kooperatif merupakan suatu pembelajaran yang didasarkan kepada paham konstruktivisme. Ini sejalan dengan Johnson (dalam Anggoro, 2015: 72) yang menjelaskan bahwa pembelajaran kooperatif sebagai pengelompokan siswa ke dalam kelompok kecil akan berdampak pada saling ketergantungan secara positif, meningkatkan tanggung jawab individual, serta proses menjadi tahu terjadi secara aktif.

Berdasarkan pemaparan di atas dapat disimpulkan bahwa dalam model pembelajaran kooperatif siswa dituntut untuk lebih bertanggung jawab atas individu dan kelompok serta siswa terlibat aktif dalam pembelajaran. Ini Sejalan dengan Ramlan (2013: 111) dalam proses pembelajaran matematika, aktivitas belajar akan efektif jika siswa berperan aktif. Siswa tidak hanya duduk mendengarkan ceramah dari guru ataupun mencatat yang dituliskan guru di papan tulis, tetapi siswa berusaha mencoba mengerjakan soal sendiri dengan bimbingan dari teman maupun guru. Siswa harus kreatif, ulet dan memiliki sikap percaya diri akan kemampuan yang dimilikinya. Diberikannya solusi lebih dari satu model pembelajaran kooperatif bisa menjadi salah satu alternatif dalam mengatasi masalah pengajar dalam memilih model apa yang cocok untuk diterapkan di kelas. Model pembelajaran kooperatif yang bisa diterapkan di sekolah tersebut adalah model pembelajaran kooperatif tipe NHT dan model pembelajaran kooperatif tipe TAI. Menurut Hadiyanti dkk (2012: 61) NHT merupakan model pembelajaran kooperatif yang dikembangkan oleh Spencer Kagan dimana model pembelajaran ini memberikan kesempatan peserta didik untuk saling membagikan ide-ide dan mempertimbangkan jawaban yang tepat.

Adapun ciri khas dari NHT adalah guru hanya menunjuk seorang siswa yang mewakili kelompoknya. Dalam menujuk siswa tersebut, guru tanpa memberi tahu terlebih dahulu siapa yang akan mewakili kelompok. Menurut Muhammad Nur dalam Azizah (dalam Alie: 2013: 585) dengan cara tersebut akan menjamin keterlibatan total semua siswa dan merupakan upaya yang sangat baik untuk meningkatkan tanggung jawab individual dalam diskusi kelompok. Selain itu dampak lain yang terjadi adalah siswa dituntut harus siap semua. Ini sejalan dengan Hadiyanti dkk (2012: 61) NHT dapat digunakan untuk mengecek pemahaman anak terhadap mata pelajaran dengan cara melibatkan lebih banyak peserta didik menelaah materi yang tercakup sehingga dapat meningkatkan penguasaan akademik dan kemampuan berfikir kritis. Kemampuan pemahaman konsep peserta didik pada materi dimensi tiga yang menerima pembelajaran dengan model pembelajaran NHT lebih baik daripada kemampuan pemahaman 
konsep peserta didik pada materi dimensi tiga yang menerima pembelajaran dengan model pembelajaran ekspositori. Hadiyanti dkk (2012:65)

Selain Model NHT, model pembelajaran kooperatif lain yang bisa digunakan adalah model pembelajaran TAI. Menurut Ramlan (2013: 111) Model pembelajaran kooperatif khususnya tipe TAI dianggap efektif dalam belajar matematika. Model Pembelajaran TAI menggabungkan pembelajaran kelompok dan individu. Berdasarkan penelitian Putri dkk (2014: 31) pemahaman konsep matematis siswa dengan menerapkan pembelajaran kooperatif tipe TAI lebih baik daripada pemahaman konsep matematis matematis siswa dengan menerapkan pembelajaran konvensional.

Rumusan masalah dalam penelitian ini adalah

1. Apakah ada perbedaan kemampuan pemahaman konsep matimatis siswa yang belajar menggunakan model pembelajaran NHT, model pembelajaran TAI serta model pembelajaran langsung?

Tujuan penelitian ini sebagai berikut:.

1. Untuk mengetahui Apakah ada perbedaan kemampuan pemahaman konsep matematis siswa yang belajar menggunakan model pembelajaran NHT, model pembelajaran TAI serta model pembelajaran langsung.

Manfaat penelitian ini hasil penelitiannya dapat dijadikan usulan positif bagi guru matematika dalam memilih model pembelajaran yang tepat untuk diterapkan dikelas

\section{METODE}

Metode yang digunakan dalam penelitian ini adalah metode Quasi-Eksperimental. Bentuk desain eksperimen ini merupakan pengembangan dari true experimental design. Desain ini mempunyai kelompok kontrol, tetapi tidak dapat berfungsi sepenuhnya untuk mengontrol variabel-variabel luar yang mempengaruhi pelaksanaan eksperimen (Lestari, dkk, 2015 :136).

Desain penelitian yang digunakan dalam penelitian ini yaitu posstest control group design. Desain penelitian dapat dituliskan sebagai berikut:

Tabel 1. Desain penelitian

\begin{tabular}{|c|c|c|c|}
\hline Eksperimen 1 & A & $\mathrm{X}_{1}$ & $\mathrm{O}$ \\
\hline Eksperimen 2 & $\mathrm{A}$ & $\mathrm{X}_{2}$ & $\mathrm{O}$ \\
\hline Kontrol & $\mathrm{A}$ & $\mathrm{X}_{3}$ & $\mathrm{O}$ \\
\hline
\end{tabular}

Keterangan :

$\mathrm{O}=$ Data Post-test

A $\quad=$ Sampel acak kelas

$\mathrm{X}_{1} \quad=$ Model pembelajaran NHT
$\mathrm{X}_{2} \quad=$ Model pembelajaran TAI

$\mathrm{X}_{3} \quad=$ Model pembelajaran Langsung

(Sugiyono, 2014: 114)

Populasi dalam penelitian ini adalah seluruh siswa kelas VIII Sekolah Menengah Pertama Negeri 16 Kota Sukabumi tahun pelajaran 2016/2017 yang terbagi ke dalam 6 kelas. Penentuan sampel yang akan dilakukan dengan sampel random atau acak. Menurut Darmawan (2013 : 148) cluster random sampling yaitu pengambilan sampel secara acak dan berumpun. Anggota sampel dalam teknik ini adalah rumpun-rumpun, kemudian dari setiap rumpun diambil rumpun kecil yang sama. Dimana dari enam kelas akan diambil menjadi tiga kelas. Cara pengambilan ketiga kelas tersebut menggunakan undian, untuk undian pertama menjadi kelas eksperimen 1 dengan perlakuan model NHT yaitu kelas VIII A, undian kedua menjadi kelas eksperimen 2 dengan perlakuan model pembelajaran TAI yaitu kelas VIII $\mathrm{F}$ dan undian ketiga menjadi kelas kontrol dengan perlakuan model pembelajaran langsung yaitu kelas VIII B.

Teknik pengumpulan data ada 3 macam yaitu 1) lembar Observasi 2) Dokumentasi 3) Metode tes . Istrumen yang digunakan dalam penelitian ini yaitu tes pemahaman konsep, lembar observasi.

Langkah-langkah pada metode tes (Lestari dan Yudhanegara, 2015: 105) sebagai berikut:

a. Menentukan indikator dari variabel yang diteliti dalam penelitian;

b. Menyusun kisi-kisi instrumen;

c. Menentukan kriteria penskoran/penilaian;

d. Merumuskan item-item pertanyaan atau pernyataan;

e. Melakukan uji coba instrumen;

f. Memberikan penskoran/penilaian;

g. Melakukan analisis hasil uji coba instrumen;

h. Menentukan instrument yang akan digunakan dalam penelitian.

Data hasil uji coba instrument selanjutnya yaitu uji validitas isi, reabilitas, tingkat kesukaran, dan daya pembedanya. Teknik analisis data yang digunakan untuk Data Awal yaitu uji prasyarat (uji normalitas dan uji homogenitas) serta uji keseimbangan sedangan untuk data posttest uji prasyarat (uji normalitas dan uji homogenitas) serta uji anava satu jalur.

\section{HASIL DAN PEMBAHASAN}

\section{Deskripsi Hasil Kemampuan Awal Pemahaman Konsep Matematis}

Data tentang kemampuan awal pemahaman konsep matematis siswa diperoleh dari data UTS . Data awal ini gunanya untuk mengetahui kemampuan pemahaman konsep matematis siswa ketiga kelas yang diambil memiliki kemampuan yang sama. 
Tabel 2. Rangkuman Hasil Uji Normalitas Kemampuan Awal

\begin{tabular}{|c|c|c|c|c|c|}
\hline $\begin{array}{l}\mathbf{N} \\
\mathbf{0 .}\end{array}$ & Sampel & Lhitung & Ltabel & $\begin{array}{l}\text { Keputus } \\
\text { an }\end{array}$ & Ket. \\
\hline 1 & $\begin{array}{c}\text { Kelas } \\
\text { Eksperimen } \\
\text { I }\end{array}$ & 0,137 & 0,161 & $\begin{array}{l}\mathrm{H}_{0} \\
\text { diterima }\end{array}$ & Normal \\
\hline 2 & $\begin{array}{c}\text { Kelas } \\
\text { Eksperimen } \\
\text { II }\end{array}$ & 0,151 & 0,161 & $\begin{array}{l}\mathrm{H}_{0} \\
\text { diterima }\end{array}$ & Normal \\
\hline 3 & $\begin{array}{c}\text { Kelas } \\
\text { Kontrol }\end{array}$ & 0,095 & 0,161 & $\begin{array}{l}\mathrm{H}_{0} \\
\text { diterima }\end{array}$ & Normal \\
\hline
\end{tabular}

Dari data tabel di atas masing-masing $\mathrm{L}_{\text {hitung }}<\mathrm{L}_{\text {tabel}}$, artinya $\mathrm{L}_{\text {hitung }}$ berada di luar daerah kritis sehingga keputusan ujinya adalah $\mathrm{H}_{0}$ diterima. Sehingga dapat disimpulkan bahwa ketiga kelas berasal dari populasi yang berdistribusi normal.

Tabel 3. Rangkuman Hasil Uji Homogenitas Kemampuan Awal

\begin{tabular}{llllll}
\hline Nama Variabel & $\mathbf{X}^{\mathbf{2}}$ hitung & $\mathbf{X}_{\text {tabel }}$ & Keputusan & Ket. \\
\hline Kelas Eksperimen & 0,037 & 5,991 & $\mathrm{H}_{0}$ diterima & Homogen \\
I,Kelas Eksperimen & & & & \\
K II dan Kelas & & & & \\
d Kontrol & & & & &
\end{tabular}

berasal dari populasi bervarians homogen.

Selanjutnya uji keseimbangan. Hal ini dimaksud agar memastikan bahwa kelas yang digunakan dalam penelitian merupakan kelas yang memiliki kemampuan yang seimbang. Uji keseimbangan digunakan untuk menguji rataan kelas eksperimen dan kelas kontrol. Dengan uji prasyarat analisis bahwa sampel berasal dari populasi berdistribusi normal dan homogen. Pada penelitian ini, uji statistik yang digunakan untuk menguji keseimbangan yaitu menggunakan uji anava satu jalur dengan sel tak sama. Hasil perhitungan uji anava satu jalan dihasilkan $\mathrm{F}_{\text {hitung }}=0.0299$ dengan $\mathrm{F}_{0,05 ; 2 ; 84}=3,11$ sedangkan daerah kritis $\mathrm{DK}=\left\{\mathrm{F}_{\mathrm{F}}>3,11\right\}$. Ini artinya $\mathrm{F}_{\text {hitung }}={ }_{0,0299} \notin D K$, sehingga $\mathrm{H}_{0}$ diterima. Dengan demikian dapat disimpulkan bahwa kemampuan awal antara kelas eksperimen I, kelas eksperimen II dan kelas kontrol mempunyai kemampuan awal yang sama. .

\section{Deskripsi Hasil Kemampuan Akhir Pemahaman} Konsep Matematis (Posttest)

Data ini diperoleh dari hasil posttest kemampuan pemahaman konsep matematis yang diperoleh setelah dilakukan perlakuan. Kelas eksperimen 1 adalah kelas yang belajar dengan model pembelajaran NHT, kelas eksperimen II yang menggunakan model pembelajaran TAI dan kelas kontrol yang menggunakan model pembelajaran langsung. Berikut ini rangkuman rerata dari data posttest.
Tabel 4. Rangkuman Hasil Uji Normalitas Kemampuan Akhir Pemahaman Konsep Matematis

\begin{tabular}{|c|c|c|c|c|c|}
\hline No. & Sampel & Rerata & $\mathbf{L}_{\text {hitung }}$ & & Keputusan \\
\hline 1 & $\begin{array}{c}\text { Kelas } \\
\text { Eksperimen } \\
\text { I }\end{array}$ & 62,41 & 0,097 & 0,161 & $\mathrm{H}_{0}$ diterima \\
\hline 2 & $\begin{array}{c}\text { Kelas } \\
\text { Eksperimen } \\
\text { II }\end{array}$ & 52,78 & 0,151 & 0,161 & $\mathrm{H}_{0}$ diterima \\
\hline 3 & $\begin{array}{c}\text { Kelas } \\
\text { Kontrol }\end{array}$ & 51,57 & 0,155 & 0,161 & $\mathrm{H}_{0}$ diterima \\
\hline
\end{tabular}

Dari tabel diatas masing-masing $\mathrm{L}_{\text {hitung }}<\mathrm{L}_{\text {tabel }}$, artinya L $_{\text {hitung }}$ berada di luar daerah kritis sehingga keputusan ujinya adalah $\mathrm{H}_{0}$ diterima. Sehingga dapat disimpulkan bahwa ketiga kelas berasal dari populasi yang berdistribusi normal.

Tabel 5. Rangkuman Hasil Uji Homogenitas Kemampuan Akhir

\begin{tabular}{ccclc} 
Nama Variabel & $\begin{array}{c}\mathbf{X}^{\mathbf{2}} \\
\text { hitung }\end{array}$ & $\mathbf{X}_{\text {tabel }}^{2}$ & \multicolumn{1}{c|}{ Kep } & Ket. \\
Kelas & 0,251 & 5,991 & $\mathrm{H}_{0}$ & Homogen \\
$\begin{array}{c}\text { Eksperimen I, } \\
\text { Kelas }\end{array}$ & & & diterima & \\
$\begin{array}{c}\text { Eksperimen II } \\
\text { dan Kelas } \\
\text { Kontrol }\end{array}$ & & & & \\
\end{tabular}

Berdasarkan hasil perhitungan Karena $\mathrm{X}^{2}$ hitung berada diluar daerah kritis, maka $\mathrm{H}_{0}$ diterima. Sehingga dapat disimpulkan bahwa sampel berasal dari populasi bervarians homogen.

\section{Pengujian Hipotesis}

Penelitian ini menggunakan analisis variansi satu jalan dengan sel tak sama karena memiliki tiga sampel yang akan diuji yaitu kelas eksperimen I yang menggunakan model pembelajaran NHT, kelas eksperimen II yang menggunakan model pembelajaran TAI dan kelas kontrol yang menggunakan model pembelajaran langsung dengan masing masing sampel memiliki jumlah siswa yang berbeda setiap kelasnya. Hasil perhitungan analisis variansi satu jalur sel tak sama dengan taraf signifikansi 0,05 disajikan pada tabel berikut:

Tabel 6. Rangkuman Analisis Variansi Satu Jalur

$\begin{array}{llll}\text { Fitung } & \text { F }_{\text {tabel }} & \text { Keputusan } & \text { Kesimpulan } \\ & & & \\ 4,705 & 3,11 & \mathrm{H}_{0} \text { ditolak } & \text { Terdapat } \\ & & & \text { perbedaan } \\ & & & \text { yang } \\ & & & \text { signifikan }\end{array}$

Berdasarkan tabel tersebut, tampak bahwa $F_{\text {hitung }}=$ 4,71 dan $\mathrm{F} \alpha=3,11$, karena $\mathrm{F}_{\text {hitung }}>\mathrm{F} \alpha$, maka $\mathrm{H}_{0}$ ditolak atau $\mathrm{H}_{1}$ diterima, Hal ini berarti terdapat perbedaan dari ketiga perlakuan tersebut. 
Berdasarkan hasil posttest yang telah dihitung didapat kesimpulan bahwa terdapat perbedaan kemampuan pemahaman konsep matematis siswa yang belajar menggunakan model pembelajaran NHT, model pembelajaran TAI serta model pembelajaran langsung.

Berdasarkan analisis data, hipotesis pertama Terdapat perbedaan kemampuan pemahaman konsep matimatis siswa yang belajar menggunakan model pembelajaran NHT, model pembelajaran TAI serta model pembelajaran langsung. Ini disebabkan adanya perbedaan perlakuan dalam proses pembelajaran.dimana kelas Eksperimen 1 dan Eksperimen 2 diterapkan suatu model pembelajaran kooperatif sedangkan kelas kontrol masih meggunakan model pembelajaran langsung.

\section{PENUTUP}

\section{Simpulan}

Berdasarkan hasil analisis data dan pembahasan dapat ditarik kesimpulan yaitu terdapat perbedaan kemampuan pemahaman konsep matimatis siswa yang belajar menggunakan model pembelajaran NHT, model pembelajaran TAI serta model pembelajaran langsung.

\section{Saran}

1. Dalam penelitian menerapkan suatu model kooperatif mengelolaan waktu lebih diperhatikan lagi.

2. Penelitian ini dapat diterapkan pada materi matematika yang lain.

\section{DAFTAR PUSTAKA}

Alie, N. H. (2013). "Penggunaan Model Pembelajaran Kooperatif Tipe NHT Untuk Meningkatkan Hasil Belajar Siswa Kelas X2 SMA Negeri 3 Gorontalo Pada Materi Jarak Pada Bangun Ruang”. Jurnal Entropi. VII, (1), 584-592.

Anggoro, R. P. (2015). "Pengaruh Pembelajaran Kooperatif Tipe NHT dan TAI dengan Pendekatan Kontekstual terhadap Partisipasi dan Prestasi Belajar Matematika”. Jurnal Pendidikan Matematika. 10, (1), 71-79.

Darmawan, D (2013) Metode Penelitian Kuntitatif bandung .PT.Remaja Rosdakarya.

Hadiyanti, R.dkk.(2012). "Keefektifan Pembelajaran Kooperatif Numbered Heads Together Terhadap Kemampuan Pemahaman Konsep". Unnes Journal of Mathematics Aducation. 1. (1), 60-65.

Lestari, K.E. dan Yudhanegara, M.R. (2015). Penelitian Pendidikan Matematika. Bandung: Refika Aditama

Monica, Dkk. (2015). “ Pengaruh pembelajaran kooperatif tipe Team Assisted individualization (TAI) terhadap hasil belajar fisika siswa kelas VII SMP Negeri 14 Lubuklinggau tahun pelajaran 2015/2016”. Jurnal Skripsi
Putri, D.S., dkk. (2014). "Pengaruh Penerapan Model Pembelajaran Kooperatif Tipe Teams Assisted Individualization Terhadap Pemahaman Konsep Matematis Siswa". Jurnal Pendidikan Matematika. 3(3), 26-31.

Ramlan, M. (2013). "Meningkatkan Self-Efficacy Pada Pembelajaran Matematika Melalui Model Kooperatif Tipe Team Assisted Individualization (TAI) Pada Siswa VII A SMP Negeri 27 Makasar" Jurnal Matematika dan pembelajaran (MAPAN). 1(1) 110121.

Rosyad, F. M. (2014). "Perbandingan Hasil Belajar siswa yang menggunakan model pembelajaran kooperatif tipe NHT dengan tipe jigsaw di SMKN 1 Jetis Mojokerto". Jurnal Pendidikan Teknik Elektro. 03,(1), 63-68

Sugiyono. (2012), Metode Penelitian Kuantitatif dan $R \& D$. Bandung : Alfabeta

Suleman, A. Rizal. (2013). Upaya Meningkatkan Pemahaman Konsep Penjumlahan Di SDN 3 Tapa Kabupaten Bone Bolango

Syaifuddin, M. W. (2013). "Eksperimentasi Model Pembelajaran Koopertif Tipe Teams Assisted Individualization (TAI) pada Pokok Bahasan Relasi dan Fungsi Ditinjau dari Kemampuan. 